\title{
Effects of $\mathrm{D}_{3} / \mathrm{D}_{2}$ Dopamine Receptor Agonists and Antagonists on Prepulse Inhibition of Acoustic Startle in the Rat
}

\author{
S. Barak Caine, Ph.D., Mark A. Geyer, Ph.D., and Neal R. Swerdlow, M.D., Ph.D.
}

Prepulse inhibition (PPI) is the normal reduction in a startle response that occurs when a weak stimulus ("prepulse") precedes the startling stimulus by 30 to 500 msec. Schizophrenic patients are deficient in this operational measure of sensorimotor gating; therefore, animal models of deficient PPI may provide information useful in the understanding and treatment of schizophrenia. Prepulse inhibition is disrupted in rats by systemic administration of direct dopamine agonists having affinity for the $D_{2}$ subtype family $\left(D_{2}, D_{3}\right.$, and $D_{4}$ ) of dopamine receptors. This study tested the hypothesis that dopamine agonists and antagonists with different affinities for $D_{3}$ and $D_{2}$ receptors differ in their relative potencies to modulate PPI. The dopamine agonists quinpirole, 7-hydroxy-N,-N-di-n-propyl-2aminotetralin (7-OH-DPAT) and apomorphine were approximately equipotent in decreasing PPI. Pretreatment with haloperidol (13 to $130 \mathrm{nmol} / \mathrm{kg} \mathrm{sc}$ ), but not equimolar doses of UH 232, prevented the disruption of PPI produced by the highest dose $(0.6 \mu \mathrm{mol} / \mathrm{kg} \mathrm{sc})$ of each agonist. Given the 100-fold higher affinity of haloperidol relative to $U H 232$ for $D_{2}$ receptors, and equal relative affinities of these antagonists for $D_{3}$ receptors, these data are consistent with previous studies suggesting that dopamine agonists may modulate PPI in the rat through the $D_{2}$ subtype of dopamine receptors. [Neuropsychopharmacology 12:139-145, 1995]
KEY WORDS: Prepulse inhibition; Sensorimotor gating; Startle; Schizophrenia; Dopamine receptor; Antipsychotic

The startle reflex to a startling stimulus is inhibited when a weak lead stimulus ("prepulse") precedes the startling stimulus by 30 to $500 \mathrm{msec}$ (Hoffman and Searle 1968; Graham 1975). This "prepulse inhibition" (PPI) of the startle reflex can be used as an operational measure of sensorimotor gating in both animals and humans (Swerdlow et al. 1986; Braff and Geyer 1990; Geyer et al. 1990; Braff et al. 1992). Schizophrenic patients exhibit deficient sensorimotor gating as measured

From the Departments of Neuroscience (SBK, MAG, NRS) and Psychiatry (NRS, MAG), University of California, San Diego, La Jolla, California.

Address correspondence to: Neal Swerdlow, M.D., Ph.D., Department of Psychiatry, 0804, University of California, San Diego, La Jolla, CA, 92093.

Received June 13, 1994; revised August 15, 1994; accepted August 22, 1994 by PPI (Braff et al. 1978, 1992), an observation consistent with the hypothesis that deficient sensory gating contributes to the cognitive fragmentation and related symptomatology associated with schizophrenia (McGhie and Chapman 1961). Studies of PPI in rats provide a valuable model for testing hypotheses about the neural substrates of deficient sensory gating in schizophrenic patients (Swerdlow et al. 1986, 1991a, 1992), as well as providing a preclinical screen for novel pharmacotherapeutic approaches for schizophrenia (Geyer et al. 1990; Rigdon and Viik 1991; Swerdlow et al. 1991b, 1994a,b; Swerdlow and Geyer 1993).

Prepulse inhibition is disrupted in rats by treatment with direct dopamine agonists having high affinities for $D_{2}$ family receptors and not by $D_{1}$ dopamine agonists (Peng et al. 1990). The disruption of PPI produced by dopamine agonists can be prevented by pretreatment with "typical" neuroleptic agents such as spiperone (Swerdlow et al. 1991b) and haloperidol (Swerdlow and 
Geyer 1993) and by pretreatment with "atypical" antipsychotics such as clozapine (Swerdlow and Geyer 1993), risperidone (Rigdon and Viik 1991), and seroquel (Swerdlow et al. 1994b). The $\mathrm{D}_{1}$ antagonist SCH23390 does not restore PPI in rats treated with apomorphine (Swerdlow et al. 1991b), although conflicting data was recently reported (Hoffman and Donovan 1994). Such studies suggest that activation of the $D_{2}$ family $\left(D_{2}, D_{3}\right.$, and $D_{4}$ ) of dopamine receptor subtypes but not the $D_{1}$ family $\left(D_{1}, D_{5}\right)$ is responsible for the disruption of PPI produced by dopamine agonists. It has been demonstrated recently that three $D_{2}$ family dopamine agonists-apomorphine, quinpirole, and 7-OH-DPAThave affinities for the $D_{3}$ receptor that correlate with their relative potencies to elicit behavioral effects (Caine and Koob 1993). The present study explored the relative contributions of specific $D_{2}$ family receptors to the neural modulation of PPI, using dopamine agonists and antagonists with different affinities for $D_{3}$ and $D_{2}$ receptors.

\section{METHOD}

\section{Subjects}

Eighty male Sprague-Dawley rats ( 225 to $250 \mathrm{~g}$; Harlan, Indianapolis, IN) were housed in pairs and maintained on a reversed 12 hour: 12 hour light/dark schedule (lights off at 0700 hours) with food and water provided ad libitum. Testing occurred during the dark phase, between 0900 and 1500 hours. Animals were handled within three days of arrival, and daily thereafter.

\section{Chemicals}

Apomorphine hydrochloride and ascorbate were obtained from Sigma Chemical Co., St. Louis, MO. Quinpirole hydrochloride and 7-OH-DPAT hydrobromide were obtained from Research Biochemicals International, Natick, MA. Haloperidol was obtained from Solopak Laboratories, Franklin Park, IL. UH 232 was generously provided by George F. Koob. All chemicals were dissolved in physiological saline except for apomorphine, which was dissolved in saline with $0.1 \%$ ascorbate, and haloperidol, which was obtained in aqueous solution containing lactic acid.

\section{Drug Treatments}

Dopamine agonists and antagonists were administered subcutaneously 5 and 10 minutes prior to testing, respectively.

\section{Apparatus}

Four startle chambers (SR-LAB, San Diego Instruments, San Diego, CA) were used, each consisting of a Plex- iglas cylinder $8.2 \mathrm{~cm}$ in diameter, resting on a Plexiglas frame within a ventilated enclosure. Acoustic noise bursts were presented via a loudspeaker mounted 24 $\mathrm{cm}$ above the animal. A piezoelectric accelerometer (assembled using a Blatek Audio Transducer Model 6030, Blatek Inc.) mounted below the Plexiglas frame detected and transduced motion within the cylinder. Stabilimeter readings were rectified and recorded by a microcomputer and interface assembly (San Diego Instruments), with $1001-\mathrm{ms}$ readings collected beginning at the stimulus onset. Startle amplitude was defined as the average of the 100 readings.

\section{Test Session}

The test session in all experiments consisted of five consecutive blocks of nine test trials each (45 trials total) with an average of 15 seconds separating each trial. A $65 \mathrm{~dB}$ background noise was constant throughout the entire test session. After a 5-minute acclimation period in the test chamber, three different trial types were delivered in pseudorandom order: startle stimulus alone (a $118 \mathrm{~dB}[\mathrm{~A}] 40 \mathrm{~ms}$ broad band burst); no stimulation; or startle stimulus preceded $100 \mathrm{~ms}$ earlier by a prepulse (a $70 \mathrm{~dB}[\mathrm{~A}] 20 \mathrm{~ms}$ broad band burst).

\section{Experiment 1: Agonist Treatments}

One week after arrival, the animals were tested in the startle session 5 minutes after subcutaneous injection of a dopamine agonist or vehicle. Every animal received a single dose (between-subject design, $n=5 /$ dose), and each animal was used for tests with only one of the agonists.

\section{Experiment 2: Antagonist Pretreatments Prior to Agonist Treatments}

Five days after Experiment 1, the animals were split into two pretreatment groups and retested after pretreatment with either haloperidol or UH 232 ( 0 to $130 \mathrm{nmol} /$ $\mathrm{kg} \mathrm{sc}$ ), and treatment (10 minutes after the pretreatment) with $0.6 \mu \mathrm{mol} / \mathrm{kg}$ of the agonist they had received in Experiment 1. Five days later, the animals were tested a third time in an identical fashion except that the pretreatment groups were reversed, so that every animal received each antagonist pretreatment once. An additional group of animals was tested with apomorphine as in Experiment 1, and then tested with UH 232, but not haloperidol, during the second startle test, and with UH 232 alone (no apomorphine) during the third startle test.

\section{Data Analysis}

Startle amplitude was analyzed using analysis of variance with repeated measures on block. Level of sig- 
nificance was $p<0.05$. A significant main effect of dose was followed by individual comparisons of each dose with the vehicle treatment (Experiments 1 and 3 ) or vehicle pretreatment (Experiment 2) using Neuman-Keul's a posteriori tests. The amount of PPI is expressed as the percentage decrease in the startle response caused by presentation of the prepulse, and was calculated using the following equation: ([startle amplitude caused by pulse alone - startle amplitude caused by pulse preceded by prepulse] / startle amplitude caused by pulse alone) $\times 100$. Using this description of PPI, a high degree of sensorimotor gating is reflected in a high "\% PPI" value, whereas less or no gating results in a small or negative "\% PPI" value. Relative potencies were calculated and analyzed using a "Manual of Pharmacologic Calculations with Computer Programs" (Tallarida and Murray 1987).

\section{RESULTS}

Experiment 1: The Dopamine Agonists 7-OH-DPAT, Quinpirole, and Apomorphine Disrupted PPI with Similar Relative Potencies

Although none of the dopamine agonists significantly altered the amplitude of the startle reflex to an acoustic startling stimulus (Figure 1A; 7-OH-DPAT, $[\mathrm{F}(3,17)=$ $0.99]$; quinpirole, $[\mathrm{F}(3,17)=2.43]$; apomorphine, $[F(3,36)=0.81])$, each of the agonists dose-dependently decreased PPI of startle (Figure 1B; 7-OH-DPAT, $[\mathrm{F}(3,17)=11.6, p<.001]$; quinpirole, $[\mathrm{F}(3,17)=15.9$, $p<.0001]$; apomorphine, $[\mathrm{F}(3,36)=16.7, p<.0001])$.

The relative potencies of the three agonists to decrease PPI (i.e., the ratio of the amounts of each drug needed to decrease PPI) were calculated using a parallel line assay of the regression lines for the dose $(\mu \mathrm{mol} /$ $\mathrm{kg}$ ) versus effect function (the correlation coefficient of the regression line for each potency estimate was $r \geqslant$ $0.7)$. With the most potent drug, quinpirole, being assigned unit potency, the relative potencies of apomorphine and 7-OH-DPAT were 1.11 and 1.26 , respectively. The relative potency values for the three agonists were not significantly different from each other (upper and lower confidence limits, 2.1 and 0.8 , respectively).

\section{Experiment 2: Haloperidol, but Not UH 232, Prevented the Disruption of PPI by Each of the Three Agonists}

Pretreatment with haloperidol ( 13 to $130 \mathrm{nmol} / \mathrm{kg} \mathrm{sc}$ ) dose-dependently reduced the disruption of PPI produced by treatment with $0.6 \mu \mathrm{mol} / \mathrm{kg}$ sc of each of the agonists (Figure 2A; haloperidol/7-OH-DPAT, [F(3, $17)=3.94, p<.05]$; haloperidol/quinpirole, $[\mathrm{F}(3,17)=$ $3.2, p<.05]$; haloperidol/apomorphine, $[\mathrm{F}(3,17)=14.8$, $p<.0001]$. In contrast, pretreatment with UH 232 (13 to $130 \mathrm{nmol} / \mathrm{kg} \mathrm{sc}$ ) did not alter PPI after treatment with $0.6 \mu \mathrm{mol} / \mathrm{kg} \mathrm{sc}$ of $7-\mathrm{OH}$-DPAT or quinpirole (Figure 2B; UH 232/7-OH-DPAT, $[\mathrm{F}(3,17)=0.21] ; \mathrm{UH}$ 232/quinpirole, $[\mathrm{F}(3,17)=1.48]$. An intermediate dose of UH $232(26 \mathrm{nmol} / \mathrm{kg} \mathrm{sc})$ increased PPI after treatment with $0.6 \mu \mathrm{mol} / \mathrm{kg} \mathrm{sc}$ apomorphine in a group of 10 animals $[F(3,17)=3.56, p<.05]$. However, this effect was not replicated in another group of ten animals $[\mathrm{F}(3,17)=0.143]$, and was not reliable across the 20 animals tested (Figure 2B; $[\mathrm{F}(3,36)=1.53]$ ). Treatment with haloperidol alone under these conditions does not significantly alter PPI (Swerdlow and Geyer 1993). UH 232 alone ( 0 to $130 \mathrm{nmol} / \mathrm{kg} \mathrm{sc}$ ) had no effect on PPI $[F(3,17)=1.20]$ (data not shown).

\section{DISCUSSION}

This study examined the relative potencies to modulate PPI of startle among $D_{2}$ family dopamine receptor agonists and antagonists having different affinities for $\mathrm{D}_{3}$ and $\mathrm{D}_{2}$ receptors. Although quinpirole and apomorphine have affinities for the $\mathrm{D}_{3}$ receptor that are approximately sevenfold and 26-fold weaker, respectively, than that of 7-OH-DPAT $\left(\mathrm{K}_{\mathrm{i}}\right.$ for $\mathrm{D}_{3}$ receptor: 7-OH-DPAT < quinpirole < apomorphine; Sokoloff et al. 1990; Levesque et al. 1992), the three agonists dosedependently disrupt PPI with equivalent relative potencies. This finding suggests that $D_{3}$ receptors may not be responsible for the disruption of PPI produced by dopamine agonists. However, the three agonists also differ in their affinities for the $\mathrm{D}_{2}$ receptor, 7-OHDPAT and quinpirole being approximately threefold and 24-fold weaker than apomorphine $\left(K_{i}\right.$ for $D_{2}$ receptor: apomorphine < 7-OH-DPAT < quinpirole). Thus no significant correlation could be found between the affinities of the three agonists for either the $D_{3}$ or the $D_{2}$ receptor and their relative potencies to disrupt $P P I$.

Importantly however, the potent $\mathrm{D}_{2}$ dopamine receptor antagonist haloperidol, but not the preferential $\mathrm{D}_{3}$ antagonist $\mathrm{UH} 232$, prevented the disruption of PPI produced by the dopamine agonists. Neither antagonist alone altered PPI under these conditions (Swerdlow and Geyer 1993; this study), suggesting that the effects of haloperidol observed here represent a specific blockade of the PPI disruption produced by the agonists. The 100 -fold higher affinity of haloperidol relative to $\mathrm{UH} 232$ for $\mathrm{D}_{2}$ receptors despite the equivalent affinities of these antagonists for $\mathrm{D}_{3}$ receptors (Sokoloff et al. 1990; Levesque et al. 1992) supports the hypothesis that dopaminergic agents modulate PPI through blockade of $D_{2}$ receptors. This hypothesis is consistent with the observation that PPI is disrupted by dopamine infusion into the anteromedial striatum (Swerdlow et al. 1992), where $D_{2}$ but not $D_{3}$ receptors are localized (Levesque et al. 1992). 

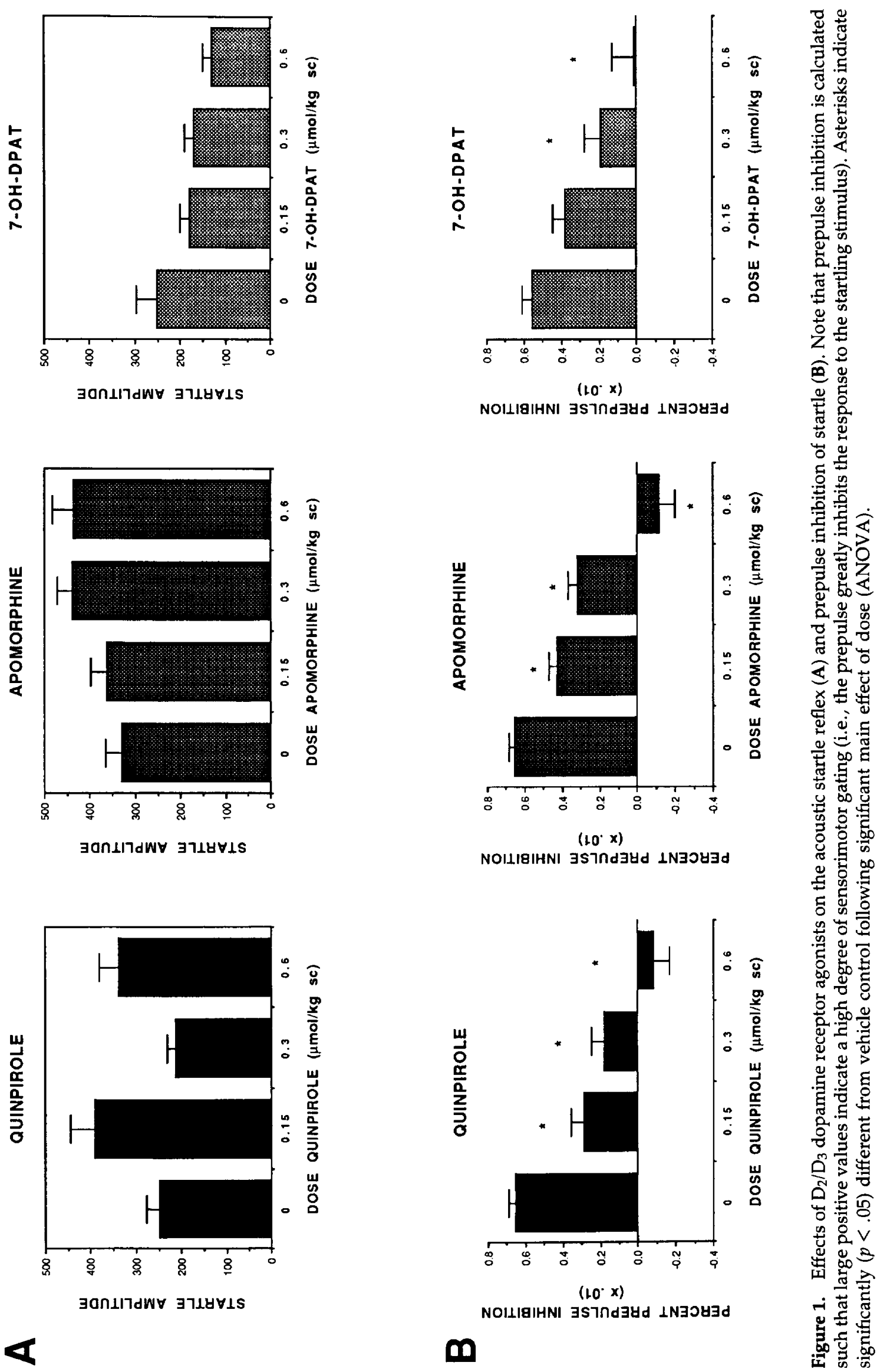

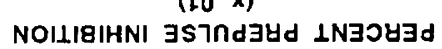

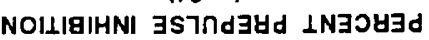




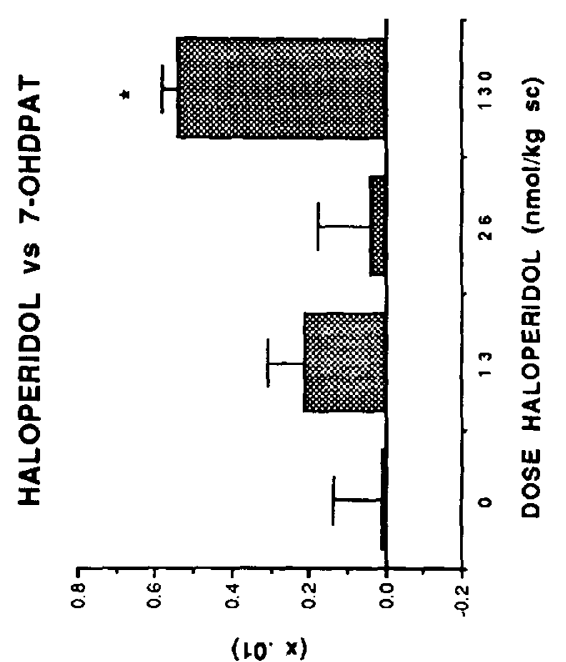

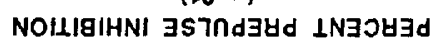
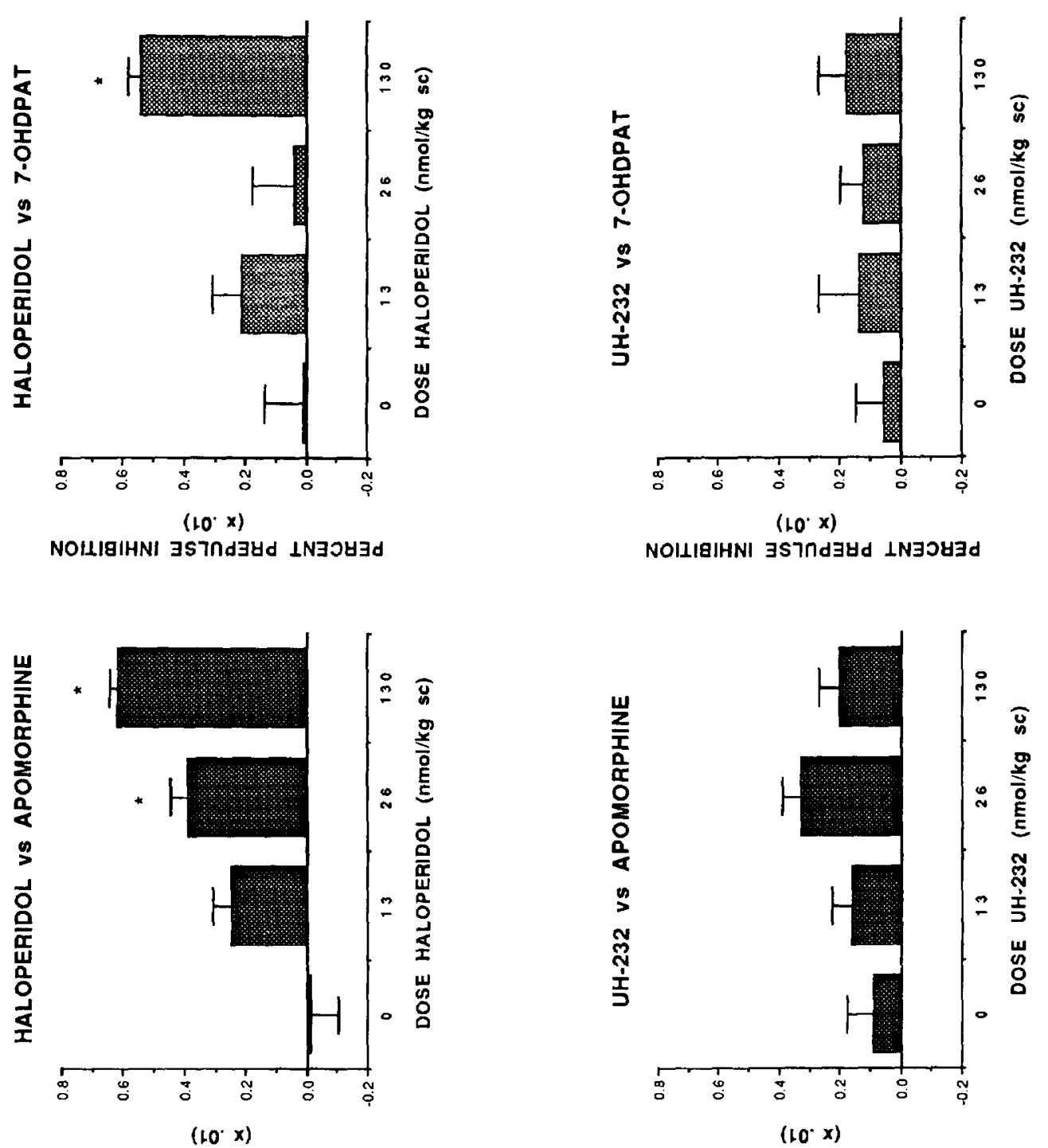

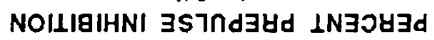

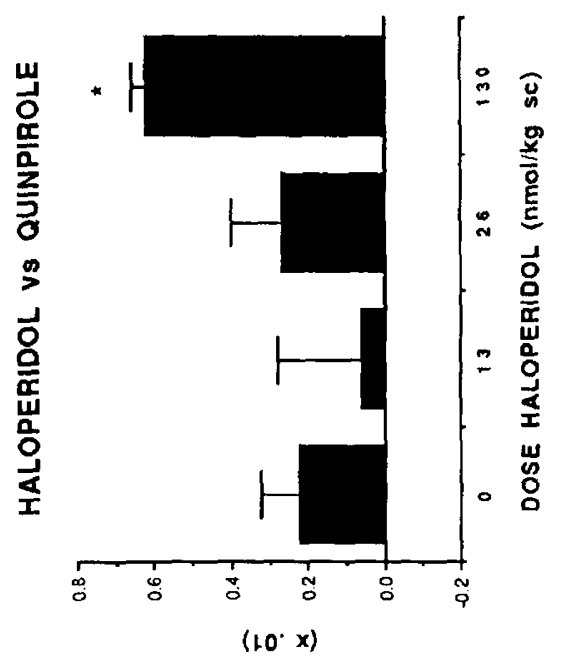

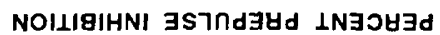
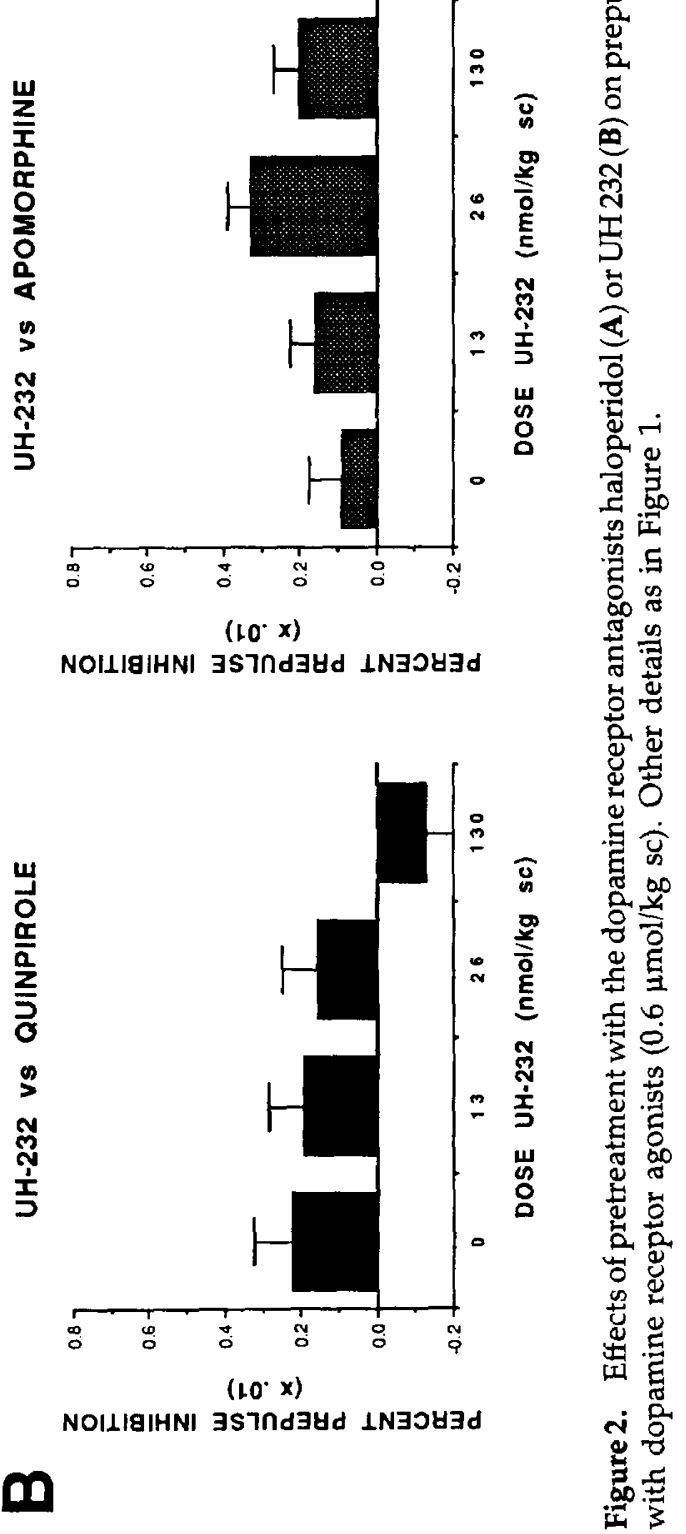
Several issues warrant consideration regarding such an interpretation of the present data. First, the affinities of agonists for $D_{3}$ versus $D_{2}$ receptors are modulated by guanine nucleotides, EDTA, magnesium, and sodium concentrations (Sokoloff et al. 1990; Levesque et al. 1992; Castro and Strange 1993; Boundy et al. 1993; Burris et al. 1994; Chio et al. 1994; Freedman et al. 1994; Tang et al. 1994); therefore, extrapolations from specific in vitro conditions to activity in vivo require caution. Two issues of particular importance are whether the three agonists tested here differ from each other in their affinities for $D_{3}$ and $D_{2}$ receptors, and whether any of the dopamine agonists (e.g., 7-OHDPAT, quinpirole) are at all "selective" for $\mathrm{D}_{3}$ versus $\mathrm{D}_{2}$ receptors (Sokoloff et al. 1990; Levesque et al. 1992; Boundy et al. 1993; Burris et al. 1994; Chio et al. 1994; Freedman et al. 1994; Tang et al. 1994). Second, given the preliminary nature of information regarding the coupling of $\mathrm{D}_{3}$ receptors to known dopaminergic effector mechanisms, the functional significance of the $D_{3}$ receptor in general remains unknown (Boundy et al. 1993; Freedman et al. 1994; Levesque et al. 1993; Chio et al. 1994). Finally, although the binding profiles of the antagonists haloperidol and UH 232 are not subject to many of the factors that modulate agonist binding, these agents may differ from each other in pharmacokinetic factors. Alternatively, UH 232 has been reported to possess stimulant-like properties, perhaps as a result of its preferential action at dopaminergic autoreceptors (Svennson et al. 1986; Piercey et al. 1992). These properties may account for the differences observed here between UH 232 and the classical neuroleptic haloperidol. Indeed, others have reported UH 232 to be inactive in behavioral tests that are sensitive to classical neuroleptics (Callahan et al. 1992).

In summary, comparisons of the dopamine receptor subtype affinities of three dopamine agonists with their relative potencies to disrupt PPI failed to conclusively implicate either the $D_{3}$ or the $D_{2}$ receptor in this effect. In contrast, of two antagonists with equal affinities for the $\mathrm{D}_{3}$ receptor, only the antagonist with 100 fold higher affinity for the $D_{2}$ receptor prevented the disruption of PPI by the dopamine agonists, supporting the hypothesis that dopaminergic agents modulate PPI through $D_{2}$ receptors. Nevertheless, given the paucity of information regarding $D_{3}$ receptor function and the lack of selective ligands to adequately discriminate between $D_{3}$ and $D_{2}$ receptors in vivo, conclusions drawn from these data need to be considered cautiously. The development of ligands with greater selectivity for specific dopamine receptor subtypes under a wide range of conditions or perhaps the use of molecular or genetic approaches (Gold et al. 1994; Wahlestedt 1994) in combination with behavioral and neurochemical techniques, may help confirm the relative contribution of specific dopamine receptor subtypes to the modulation of PPI. These issues may be important for determining the neural bases of deficient sensorimotor gating in schizophrenic patients, and may facilitate the development of novel pharmacotherapies for the treatment of schizophrenia.

\section{ACKNOWLEDGMENTS}

We would like to acknowledge the generous support of Sandoz Pharmaceuticals (Basel, Switzerland). We also thank Pam Auerbach for excellent technical assistance. Also supported by NIMH grants MH48381 (NRS) and MH42228 (NRS, MAG) and NIDA predoctoral fellowship DA05478 (S.B.C.). All animal procedures were performed in accordance with the Guide for the Care and Use of Laboratory Animals endorsed by the NIH.

\section{REFERENCES}

Boundy VA, Luedtke RR, Gallitano AL, Smith JE, Filtz TM, Kallen RG, Molinoff PB (1993): Expression and characterization of the rat $\mathrm{D}_{3}$ dopamine receptor: Pharmacologic properties and development of antibodies. J Pharmacol Exp Ther 264:1002-1011

Braff DL, Geyer MA (1990): Sensorimotor gating and schizophrenia: Human and animal studies. Arch Gen Psychiatry 47:181-188

Braff D, Stone C, Callaway E, Geyer M, Glick I, Bali L (1978): Prestimulus effects of human startle reflex in normals and schizophrenics. Psychophysiology 15:339-343

Braff DL, Grillon C, Geyer MA (1992): Gating and habituation of the startle reflex in schizophrenic patients. Arch Gen Psychiatry 49:206-215

Burris KD, Filtz TM, Chumpradit S, Kung M-P, Foulon C, Hensler JG, Kung HF, Molinoff PB (1994): Characterization of $\left[{ }^{125} \mathrm{I}\right](R)$-trans-7-Hydroxy-2-( $N$-propyl- $N$ - (3'-iodo2 -propenyl)amino]tetralin binding to dopamine $D_{3}$ receptors in rat olfactory tubercle. J Pharmacol Exp Ther 268:935-942

Caine SB, Koob GF (1993): Modulation of cocaine selfadministration in the rat through D-3 dopamine receptors. Science 260:1814-1816

Callahan PM, Piercey MF, Cunningham KA (1992): Effects of the putative dopamine autoreceptor antagonists $(+)-$ AJ 76 and $(+)-$ UH 232 on the discriminative stimulus properties of cocaine. Psychopharmacology 107:73-77

Castro SW, Strange PG (1993): Coupling of $D_{2}$ and $D_{3}$ dopamine receptors to G-proteins. Fed Eur Biochem Soc 315:223-226

Chio CL, Lajiness ME, Huff RM (1994): Activation of heterologously expressed D3 dopamine receptors: Comparison with D2 dopamine receptors. Mol Pharmacol 45:51-60

Freedman SB, Patel S, Marwood R, Emms F, Seabrook GR, Knowles MR, McAllister G (1994): Expression and pharmacological characterization of the human $D_{3}$ dopamine receptor. J Pharmacol Exp Ther 268:417-426

Geyer MA, Swerdlow NR, Mansbach RS, Braff DL (1990): Startle response models of sensorimotor gating and habituation deficits in schizophrenia. Brain Res Bull 25:485-498 
Gold LH, Xu M, Polis I, Heyser C, Tonegawa S, Koob GF (1994): Reduced responsiveness of D1 receptor deficient mice to the effects of D1 selective agonists, antagonists and d-amphetamine in tests of locomotor activity and catalepsy. Soc Neurosci Abstr 20:1623

Graham FK (1975): The more or less startling effect of weak prestimuli. Psychophysiology 12:238-248

Hoffman DC, Donovan H (1994): D1 and D2 dopamine receptor antagonists reverse prepulse inhibition deficits in an animal model of schizophrenia. Psychopharm 115: 447-453

Hoffman HS, Searle JL (1968): Acoustic and temporal factors in the evocation of startle. J Acoust Soc Am 43:269-282

Levesque D, Diaz J, Pilon C, Martres M-P, Giros B, Souil E, Schott D, Morgat J-L, Schwartz J-C, Sokoloff P (1992): Identification, characterization, and localization of the dopamine $\mathrm{D}_{3}$ receptor in rat brain using 7-[3H]hydroxy$N-N$-di- $n$-propyl-2-aminotetralin. Proc Natl Acad Sci USA 89:8155-8159

Levesque D, Sokoloff P, Martres M-P, Diaz J, Dimitriadou V, Pilon C, Schwartz J-C (1993): Function and regulation of the D3 dopamine receptor. Soc Neurosci Abstr 19:1369

McGhie A, Chapman J (1961): Disorders of attention and perception in early schizophrenia. Br J Med Psychol 34: 103-116

Peng RY, Mansbach RS, Braff DL, Geyer MA (1990): A D2 dopamine receptor agonist disrupts sensorimotor gating in rats: Implications for dopaminergic abnormalities in schizophrenia. Neuropsychopharmacology 3:211-218

Piercey MF, Lum JT, Hoffman WE, Carlsson A, Ljung E, Svennson K (1992): Antagonism of cocaine's pharmacological effects by the stimulant dopaminergic antagonists, $(+)-$ AJ 76 and (+) - UH 232. Brain Res 588:217-222

Rigdon GC, Viik K (1991): Prepulse inhibition as a screening test for potential antipsychotics. Drug Dev Res 23:91-99

Schwartz J-C, Giros B, Martres M-P, Sokoloff P (1992): The dopamine receptor family: molecular biology and pharmacology. Sem Neurosci 4:99-108

Sokoloff P, Giros B, Martres M-P, Bouthenet ML, Schwartz J-C (1990): Molecular cloning and characterization of a novel dopamine receptor $\left(\mathrm{D}_{3}\right)$ as a target for neuroleptics. Nature 347:146-151
Svennson K, Johansson AM, Magnusson T, Carlsson A (1986): $(+)-$ AJ 76 and (+)-UH 232: Central stimulants acting as preferential dopamine autoreceptor antagonists. Naunyn-Schmiedeberg's Arch Pharmacol 334:234-245

Swerdlow NR, Braff DL, Geyer MA, Koob GF (1986): Central dopamine hyperactivity in rats in mimics abnormal sensory gating of the acoustic startle response in schizophrenics. Biol Psychiatry 21:23-33

Swerdlow NR, Caine SB, Braff DL, Geyer MA (1991a): Neural substrates of sensorimotor gating of the startle reflex: a review of recent findings and their implications. J Psychopharmacol 6:176-190

Swerdlow NR, Keith VA, Braff DL, Geyer MA (1991b): The effects of spiperone, raclopride, $\mathrm{SCH} 23390$, and clozapine on apomorphine-inhibition of sensorimotor gating of the acoustic startle response in the rat. J Pharmacol Exp Ther 256:530-536

Swerdlow NR, Caine SB, Geyer MA (1992): Regionally selective effects of intracerebral dopamine infusion on sensorimotor gating of startle in the rat. Psychopharmacology 108:189-195

Swerdlow NR, Geyer MA (1993): Clozapine and haloperidol in an animal model of sensorimotor gating deficits in schizophrenia. Pharmacol Biochem Behav 44:741-744

Swerdlow NR, Braff DL, Taaid N, Geyer MA (1994a): Assessing the validity of an animal model of deficient sensorimotor gating in schizophrenic patients. Arch Gen Psychiatry 51:139-154

Swerdlow NR, Zisook D, Taaid N (1994b): Seroquel (ICI $204,636)$ restores prepulse inhibition of acoustic startle in apomorphine-treated rats: Similarities to clozapine. Psychopharmacology 114:675-678

Tallarida RJ, Murray RB (1987): Manual of Pharmacologic Calculations with Computer Programs. Springer-Verlag, New York

Tang L, Todd RD, Heller A, O'Malley KL (1994): Pharmacological and functional characterization of $\mathrm{D}_{2}, \mathrm{D}_{3}$, and $\mathrm{D}_{4}$ dopamine receptors in fibroblast and dopaminergic cell lines. J Pharmacol Exp Ther 268:495-502

Wahlestedt C (1994): Antisense oligonucleotide strategies in neuropharmacology. Trends Neurosci 15:42-46 